\title{
Bulk utilization of industrial waste (bauxite residue) for production of red mud concrete
}

\author{
Deshmukh M.P. ${ }^{1^{*}}$, Sarode D.D. ${ }^{2}$ \\ ${ }^{I}$ Research Scholar, Deptt of General Engg, Institute of Chemical Technology, Mumbai, India. \\ ${ }^{2}$ Associate Professor, Dept. of General Engg, Institute of Chemical Technology, Mumbai, India.
}

\begin{abstract}
The high-alkaline red coloured, dust-like industrial waste (bauxite residue) from allumina industry has already crossed the mark of 3 billion tonnes, globally. Every year about 120 million tonnes of bauxite residue is freshly disposed off into stock-piling yards. Bulk utilization of bauxite residue (red mud) has been, and continue to be a great challenge for all the stake-holders of the aliumaia industry. Concrete is the second largest consumable material in the world. Annual consumption of concrete and allied products is over 20 billion tonnes per annum, globally. Ever increasing demand of concrete for housing and infrastructure construction is posing a great threat to the environmental. In this paper, an attempt is made here, to utilize red mud as a partial substitute material for fine particles in concrete. For this, an experimental study is carried out by casting concrete cube moulds for $0 \%$ (control mix), 7\%, 14\%, 21\%, 28\% replacement of fine particles in concrete with red mud. It is found that red mud concrete, thus produced, gives better compressive strength to the concrete. Thus bulk utilization of red mud in concrete will reduce it's content in stock-piling yards of allumina industries, It would also conserve natural materials to support sustainable development.
\end{abstract}

Keywords: Aggregate, bauxite residue, red mud concrete, sustainable development, tensile.

\section{Introduction}

Concrete is the second largest consumable material in the world. It is likely to grow in a geometric proportion in near future. Cement. Fine aggregates, course aggregates, etc. are the main ingredients of concrete. Production of cement is an energy intensive process and liberates an equivalent amount of carbon di-oxide into the nature. There is a limitation on consumption of natural and artificial aggregates. Hence, there is an urgent need to explore for substitutes of concrete constituents. Industrial wastes such as fly-ash, boiler slag, bottom ash, etc. is already being used since long in concrete.

Disposal of large quantities industrial waste on land is posing a great threat to the environment, leading to cause some serious issues of pollution of land, water and air. According to an estimate, by the year 2025, the annual generation of solid waste is likely to reach 19 billion tones. Aluminum metal is an important strategic material with global annual production of some 50 million tons. It ranks third after oxygen and silicon in abundance in the earth's crust. It consists of many rocks, minerals and ores and has to undergo many chemical and electrolytic processes before its formation. Majority of the aluminum is derived from alumina. It is one of the largest industrial by-products in modern society estimated at about 3000 million tones at the end of 2010 (Power et al, 2009) and the global inventory is growing approximately by 120 million tons per annum. Sources of bauxite and the mineralogical process parameters determines the chemical and mineralogical composition of bauxite residue. About 1-1.6 tons of red mud is generated per tons of alumina. The disposal cost of red mud is also very high (1-2\% of alumina price). Even after conducting thousands of trials and undertaking hundreds of patents matching the tonnage arising annually, bulk utilization of red mud continues to be a major challenge. It is well established that red mud can be used in various cement and cement based composites for production of building blocks, tiles, paver blocks, bricks, precast components, etc. With more and more innovative ways of using these materials, it is possible to reduce the consumption of conventional concrete as building materials and to substitute them partly or fully with red mud. Thus leads not only to sustainable development but also reduce the pollution effects on environment of stock piling of red mud. Utilization of red mud in construction would help to develop cleaner and greener environment.

\section{Material And Methods:}

The materials used in the presented research are described as the following:

- Cement: 53 Grade grade-Ordinary portland cement, Associate Cement companies (specific gravity-3.15)

- Red mud : Hindalco,Belgaon,Karnataka,India,(specific gravity-3.10)

- Fine aggregate:CFA from Tata,Bhayenderpada,Thane with specific gravity 2.65

- Coarse aggregate: CA from Tata,Bhayenderpada,Thane with specific gravity 2.87.

- Naphta based admixture $1.5 \%$. 
- $\quad$ Fly-ash: Tata Fly-ash with specific gravity 2.89

The Chemical composition and of red mud are given below.

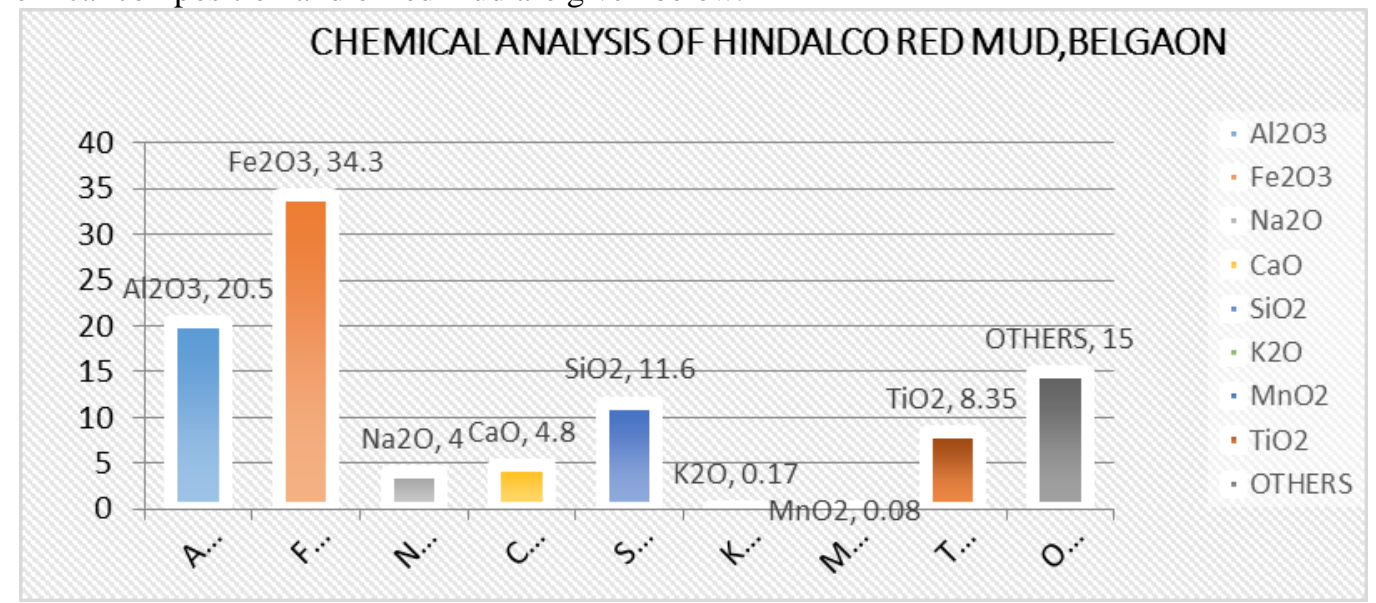

Figure 1 : Chemical composition of red mud from Hindalco, Belgaon, Karnataka, India..

All the trials are being carried out at ACC Lab,Thane,India as per IS 516:1999.

Cement and Fly-ash are taken in the ratio 1:1 as a cementitios mass. Design mix of 1:2.04:3.49 is prepared and 10 concrete cubes of size $15 \mathrm{~cm}^{*} 15 \mathrm{~cm} * 15 \mathrm{~cm}$ are cast and cured as per IS 516:1999. This mix is taken as a Control mix and the cubes are then tested for compressive strength of 3,7 and 28 days under compression testing machine. Flexural strength is determined for the beams of size $75 \mathrm{~cm}^{*} 15 \mathrm{~cm} * 15 \mathrm{~cm}$, at 28 days from the date of casting per IS 516:1999. Fine aggregates are then replaced with the raw red mud from Belgaon,Karnataka with of $7 \%, 15 \%, 21 \%$ and $28 \%$ replacements of crushed stone fine aggregates with various trials.

Sieve analysis and particle size distribution of fine particles of red mud and fine crushed aggregate is studied and accordingly the red concrete mix is designed.

The pozzolanic properties of red mud due to presence of allumina,silica, ferrous oxide and the binding properties due to presence of calcium oxide helps red mud to develop higher early strength in case of red mud concrete. It was observed that addition of red mud increases the quantity of water required for setting and hardening of red mud concrete. This increase in water/cement ratio reduces the concrete strength considerably. It is also recorded that addition of Naptha-based admixture improves the compressive and flexural strength of red mud concrete.

\section{Result And Discussions:}

Batch number 556 represents control mix 0\% CFA replacement with red mud in $350 \mathrm{~kg} / \mathrm{m}^{3}$ of cement and fly-ash in the proportion (1:1). Batch number 574, 580, 591 and 614 represents $7 \%, 14 \%, 21 \%$ and $28 \%$ replacement of fines with corresponding quantity of red mud respectively.

It can be observed that the best results of compressive strength and flexural strength are obtained for batch no 580 ( $14 \%$ replacement of fines with red mud). Even at $28 \%$ replacement of fines with red mud ,compressive strength and flexural strength is better as compared to controll mix. The compressive and flexural strength values of controll mix and the trial no. 591 are found to be lower compared to rest of the results. It has been observed from the past experiments that the compressive and flexural values of controll mix are better than the red mud substituted trials. Generally, addition or substitution with red mud does not improve the values of compressive and flexural strengths appreciably, but in our experimental study,it happened. The increase in strength after replacement of fines from concrete with varying percentages of red mud is due to the addition of admixture in red mud concrete. Results are tabulated in table 1.

TABEL 1 :Compressive and flexural strength of concrete.

\begin{tabular}{|l|l|l|l|l|l|}
\hline $\begin{array}{l}\text { Batch } \\
\text { Number }\end{array}$ & Symbol & $\begin{array}{l}\text { Three-day } \\
\text { Compressive } \\
\text { Strenth (Mpa) }\end{array}$ & $\begin{array}{l}\text { Seven-day } \\
\text { compressive } \\
\text { Strenth (Mpa) }\end{array}$ & $\begin{array}{l}\text { Twenty eight day } \\
\text { Compressive } \\
\text { strength (Mpa) }\end{array}$ & $\begin{array}{l}\text { Twenty eight day } \\
\text { Flexural strength (Mpa) }\end{array}$ \\
\hline 556 & R00C350 & 09.34 & 13.78 & 26.23 & 2.8 \\
\hline 574 & R07C350 & 15.11 & 17.78 & 31.11 & 3.2 \\
\hline 580 & R14C350 & 14.67 & 21.78 & 31.11 & 4.4 \\
\hline 591 & R21C350 & 14.22 & 21.34 & 24.89 & 3.8 \\
\hline 614 & R28C350 & 12.45 & 17.78 & 29.78 & 3.0 \\
\hline
\end{tabular}




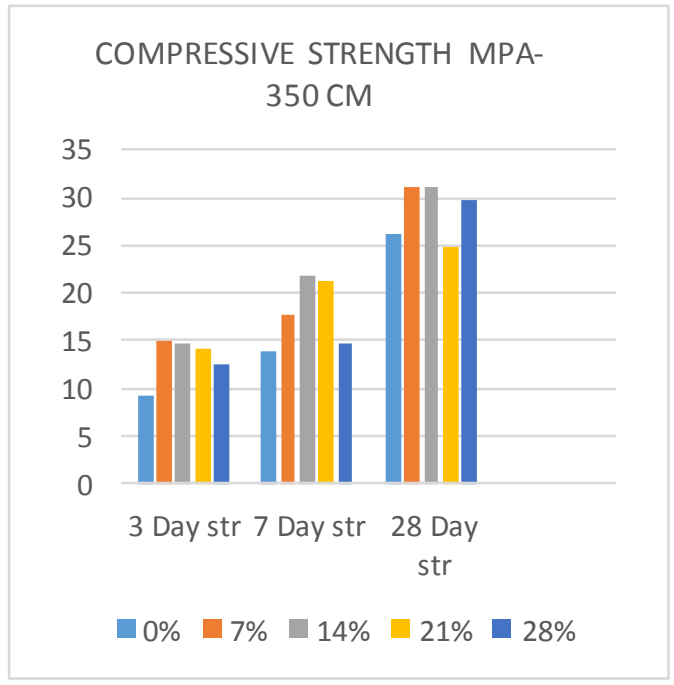

Figure 2:Compressive strength of concrete

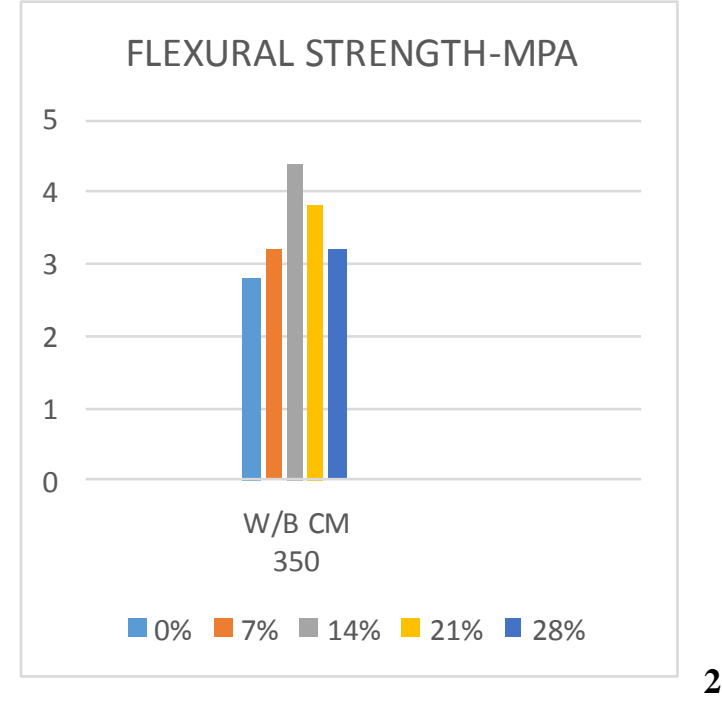

Figure 3 : flexural strength of concrete.

\section{Conclusions}

It is clear from the above experimental results that;

- Replacement of $14 \%$ of the fines content in concrete with an industrial waste of allumina industry (red mud) improves the compressive strength of concrete from 26.33 MPA to 31.11 MPA and corresponding flexural strength of concrete increases from 2.8 to 4.4 .

- Replacement of $0 \%$ and $21 \%$ of the fines content of concrete with an industrial waste of allumina industry(red mud) represents lower values of compressive and flexural strength

- Additon of red mud in concrete increases the water demand. Incresed water-cement ratio deceases the strength of concrete. Hence replacement of fines in concrete with red mud needs to be carried out by keeping a strict control on water/binder ratio. Compatible admixture addition may also helps to improve the properties of concrete. Hence there is a scope for development of innovative concrete products such as concrete wall blocks, panels, paver blocks, chequered tiles,etc. This will also help to support the mission of "Clean India " by reducing and recycling of high alkalline red mud in concrete and promote bulk utilization of red mud in concrete. It would also reduce the consumption of natural resources for sustainable developments.

\section{References}

[1]. Power, G., Grafe, M., and Klauber, C., "Review of Current Bauxite Residue Management, Disposal and Storage: Practices, Engineering and Science.” CSIRO Document DMR-3609 (2009).

[2]. Indian Aluminium Industry "Indian Primary Aluminium Market”(2009). Available www.scribd.com/doc/.../19149792Indian-Aluminium-Industry.

[3]. Annual report, Chapter V, Department of Ministry of Mines, India 1999-2000, Available:http://mines.nic.in/archp5.html; http://www.portal.gsi.gov.in/gsiDoc/pub/DID_Bauxite_WM.pdf

[4]. Yoshizawa S, Tanaka M, Shedder AV. Global trends in waste generation. In: Gab Allah I, Mishra B, Solozabal $\mathrm{R}$, T an aka M, editors. Recycling, waste treatment and cle a n technology. Spain: TMS Mineral, Metals and Materials publishers; 2004. p. 1541-52 (II).

[5]. Kumar S, Kumar R, Bandopadhyay A., Innovative methodologies for the utilization of wastes from metallurgical and allied industries. Resources, Conservation and Recycling. 2006 ; (48):301-314.

[6]. Aluminum Association (2000), "Technology Roadmap for Bauxite Residue Treatment and Utilization".

[7]. Banvolgyi, G. Huan, T. M., "De-watering, disposal and utilization of red mud: state of the art and emerging technologies".

[8]. Jamaican Bauxite Institute and the University of the West Indies, "Bauxite Tailings "Red Mud", Proceedings of International Workshop Kingston, Jamaica, October 1986.

[9]. Jones, B.E. H., and Haynes, R.J., "Bauxite Processing Residue: A Critical Review of Its Formation, Properties, Storage, and Revegetation", (2011)

[10]. Critical Review Environ. Sci. and Tech., (41) 271-315. Klauber, C., Grafe, M., and Power, G, "Review of Bauxite Residue "Reuse" Options", CSIRO Document DMR-3609 (2009). 